\title{
Mediastinal Lipoma
}

National Cancer Institute

\section{Source}

National Cancer Institute. Mediastinal Lipoma. NCI Thesaurus. Code C6599.

A benign adipose tissue neoplasm of the anterior, middle or posterior mediastinum. 